\title{
ANALISIS KESALAHAN DALAM MENYELESAIKAN MASALAH MATEMATIKA DENGAN MENGGUNAKAN LANGKAH POLYA SISWA KELAS VII SMP
}

\author{
Maria Kristofora Wati $^{1}$, A. A Sujadi ${ }^{2}$ \\ ${ }^{1,2)}$ Program Studi Pendidikan Matematika, FKIP \\ Universitas Sarjanawiyata Tamansiswa Yogyakarta \\ ${ }^{1)}$ mariakristofora93@gmail.com
}

\begin{abstract}
ABSTRAK
Penelitian ini bertujuan untuk mengetahui persentase kesalahan terbesar yang dilakukan siswa dalam menyelesaikan masalah matematika pada materi himpunan. Jenis penelitian ini adalah deskriptif kualitatif. Subyek penelitian ini adalah siswa kelas VIIA SMP Taman Dewasa Ibu Pawiyatan yang berjumlah 26 orang.Teknik pengumpulan data menggunakan teknik tes dan wawancara. Keabsahan data dilakukan dengan triangulasi metode dengan membandingkan data hasil tes dan wawancara. Teknik analisis data dilakukan dengan tahapan 1) menelaah semua data yang terkumpul, 2) menelaah hasil pekerjaan siswa, 3) melakukan penarikan kesimpulan dari data. Kerangka analisis dikembangkan berdasarkan kategori kesalahan Polya. Hasil Penelitian ini diperoleh empat jenis kesalahan dan besar persentase untuk setiap jenis kesalahan yaitu kesalahan memahami masalah $49,36 \%$, kesalahan menyusun atau membuat rencana $26,92 \%$, kesalahan melaksanakan rencana $34,16 \%$, dan kesalahan memeriksa kembali jawaban 41,5\%. Hasil menunjukan kesalahan memahami masalah dan lebih dominan dibandingkan dengan kesalahan lainnya. Kesalahan tahap pertama dan kedua merupakan kesalahan konsep dan prinsip, kesalahan ketiga merupakan kesalahan prosedur dan algoritma dan kesalahan tahap empat merupakan kesalahan penegasan jawaban.
\end{abstract}

Kata Kunci : Analisis Kesalahan, Penyelesaian Masalah, Masalah Matematika.

\section{PENDAHULUAN}

Pendidikan merupakan sebuah proses dengan metode - metode tertentu sehingga seseorang memperoleh pengetahuan, pemahaman, dan cara bertingkahlaku sesuai dengan kebutuhan. sebagian orang memahami arti pendidikan sebagai pengajaran karena pendidikan pada umumnya selalu membutuhkan pengajaran (Syah, 2005).

Matematika merupakan ilmu dasar yang digunakan secara luas dalam segala bidang kehidupan manusia, sehingga diperlukan suatu upaya dalam pengajaran matematika agar dapat terlaksana secara optimal dan siswa dapat memahami matematika dengan baik. Matematika bukan hanya ketrampilan berhitung, tetapi juga mencakup konsep dan struktur matematika (Hudojo, 2005). Pendidikan matematika adalah salah satu esensi terpenting dalam dunia pendidikan, karena hampir semua konteks kehidupan sehari - hari berhubungan dengan matematika. Perkembangan matematika juga semakin pesat, baik materi maupun kegunaannya. 
Menurut Gagne belajar adalah perubahan disposisi atau kemampuan yang dicapai seseorang melalui aktivitas. Perubahan disposisi tersebut bukan diperoleh langsung dari proses pertumbuhan seseorang secara alamiah. Belajar terdiri dari tiga komponen penting yaitu kondisi eksternal, kodisi internal dan hasil belajar (Uno, 2008).

Pembelajaran adalah upaya menciptakan iklim dan pelayanan terhadap kemampuan, potensi, minat, bakat, dan kebutuhan siswa yang beragam agar terjadi interaksi optimal menyimpulkan sebagai berikut. Pembelajaran matematika adalah suatu proses atau kegiatan guru mata pelajaran matematika dalam mengajarkan matematika pada siswanya, yang di dalamnya terkandung upaya guru untuk menciptakan iklim dan pelayanan terhadap kemampuan, potensi,minat, bakat, dan kebutuhan siswa tentang matematika yang amat beragam agar terjadi interaksi optimal antar guru dengan siswa sertaantara siswa dengan siswa dalam mempelajari matematika tersebut (Suyitno, 2004).

Dalam pembelajaran matematika, seringkali siswa memahami konsep pada materi yang sedang dipelajari, akan tetapi salah dalam menerapkan rumus yang akan digunakan untuk menyelesaikan masalah matematika. Adapula siswa yang tidak mengerti konsep pada materi yang sedang dipelajari, namun dalam menyelesaikan masalah matematika menghasilkan jawaban yang tepat karena menggunakan unsur logika dari diri sendiri. Begitu pula kesalahan siswa yang sering terjadi karena kesalahan perhitungan. Siswa memahami konsep dan prosedur pada materi yang sedang dipelajari, akan tetapi siswa seringkali tidak teliti dengan perhitungan atau komputasi sehingga menyebabkan adanya kesalahan pada permasalahan matematika (Sahriah, 2012).

Adanya kesalahan yang dilakukan siswa dalam menyelesaikan masalah matematika perlu mendapat perhatian dan perlu diidentifikasi. Informasi tentang kesalahan dalam menyelesaikan masalah matematika dapat digunakan untuk meningkatkan kegiatan belajar mengajar matematika dan akhirnya diharapkan dapat meningkatkan prestasi belajar matematika. Keberhasilan siswa dapat dilihat dari kemampuan siswa dalam menyelesaikan masalah matematika yang membutuhkan tahapan - tahapan tertentu untuk mendapatkan penyelesaiannya. Seperti pada Tahapan Polya, dalam menyelesaikan masalah matematika harus merujuk pada empat tahapan penting. Yaitu: 1) Memahami masalah (Understanding the problem) 2) Memikirkan rencana (Devising a plan) 3) Melaksanakan rencana (Carrying out the plan) 4) Memeriksa kembali jawaban (Looking back). Tahapan - tahapan penyelesaian masalah yang ditemukan oleh George Polya ini merupakan metode esensial untuk menyeleksi informasi yang relevan. Informasi tersebut berupa data dan permasalahan yang akan dicari 
Jurnal PRISMA Universitas Suryakancana

penyelesaiannya. Penyelesaian permasalahan ini belum dianggap sebagai hasil final sebelum diperiksa kembali kesesuaiannya terhadap informasi yang disediakan (Suherman, 2001).

Peneliti menggunakan penyelesaian masalah dengan menggunakan tahapan Polya dalam penelitian ini karena langkah Polya menyediakan kerangka kerja yang tersusun rapi untuk menyelesaikan masalah. Beberapa hasil penelitian yang telah dilakukan sebelumnya menunjukan bahwa penyelesaian dengan menggunakan langkah Polya sangat efektif. Maka peneliti mencoba menggunakan langkah - langkah Polya untuk menngetahui kesalahan yang dilakukan siswa untuk menyelesaikan masalah matematika pada pokok bahasan himpunan. Hal ini dilakukan untuk mempermudah dalam pembelajaran dalam penyelesaian masalah soal uraian melalui langkah - langkah Polya dengan harapan dapat mengulangi kesalahan kesalahan yang dilakukan siswa dan kemampuan siswa dalam menyelesaikan soal uraian matematika dapat ditingkatkan.

\section{METODE PENELITIAN}

Penelitian ini dilakukan Jenis penelitian ini adalah kualitatif deskriptif. Penelitian kualitatif adalah suatu pendekatan penelitian yang mengungkap situasi sosial tertentu dengan mendeskripsikan kenyataan secara benar, dibentuk oleh kata - kata berdasarkan teknik pengumpula dan analisis data yang relevan yang diperoleh dari situasi yang alamiah (Komariah \& Satori, 2014) Penelitian deskriptif digunakan untuk melihat dan menggambarkan masalah atau fakta yang sedang terjadi yang diungkapkan tanpa ada manipulasi (Sugiyono, 2010).

Subjek penelitian ini adalah siswa kelas VIIA semester genap SMP Taman Dewasa Ibu Pawiyatan Yogyakarta pada tahun 2016/2017 yang berjumlah 26 siswa. Teknik pengumpulan data yang digunakan dalam penelitian ini meliputi meliputi : (1) metode pokok berupa tes untuk pengumpulan data yang kemudian diolah dan dianalisis, (2) metode bantu yaitu : (a) wawancara untuk mengetahui penyebab kesalahan.

Teknik pengumpulan data menggunakan teknik tes dan wawancara. Analisis data yang digunakan dalampenelitian ini menggunakan tahapan - tahapan dari Moleong (2000), yaitu : 1) menelaah semua data yang terkumpul dari berbagai sumber, 2) menelaah hasil pekerjaan siswa dalam menyelesaikan masalah matematika hasil penelaahan ini kemudian dikonsultasikan dengan indikator - indikator kesalahan untuk mengetahui jenis - jenis kesalahan yang dilakukan oleh siswa, 3) verifikasi data/ penarikan kesimpulan merupakan proses perumusan makna dari hasil penelitian yang diperoleh, pada tahap verifikasi dilakukan 
peninjauan terhadap kebenaran dari penyimpulan, berkaitan dengan relevansi dan konsistensinya dengan judul, tujuan dan perumusan masalah (Widodo, 2013).

Untuk mengetahui presentase setiap jenis kesalahan digunakan rumus berikut.

$$
P_{i=\frac{E_{i}}{N \times M_{i}} \times 100}
$$

Keterangan :

$\mathrm{Pi} \quad=$ persentase kesalahan item soal ke-I, $\mathrm{i}=1,2, \ldots, 6$

$E i=$ total skor kesalahan pada item soal ke-i

$N \quad=$ banyak seluruh siswa

$M i=$ skor kesalahan maksimal pada item soal ke-i

\section{HASIL DAN PEMBAHASAN}

\section{Kesalahan dalam Memahami Masalah}

Pada soal nomor 1 diperoleh bahwa 5 siswa (12,3\%) tidak menyampaikan hal - hal yang diketahui, 25 siswa $(96,2 \%)$ tidak menyampaikan hal - hal yang di tanyakan dan 5 siswa $(13,5 \%)$ tidak menyampaikan hal - hal yang diketahui dan hal - hal yang ditanyakan sekaligus. Pada soal nomor 2 terdapat 26 siswa (73\%) tidak menyampaikan ha - hal yang diketahui, 26 siswa (100\%) tidak menyampaikan hal - hal yang ditanyakan dan 26 siswa $(77,6 \%)$ tidak melakukan dua jenis kesalahan sekaligus yakni hal - hal yang diketahui dan yang ditanyakan. Pada sosal nomor 3 diperoleh bahwa 8 siswa $(28,2 \%)$ tidak menyampaikan apa yang diketahui, 26 siswa (100\%) tidak menyampaikan apa yang ditanyakan dan 8 siswa tidak menyampaik dua kesalahan sekaligus yakni apa yang diketahui dan ditanyakan. Pada soal nomor 4 terdapat 12 siswa (41,3\%) tidak menyampaikan apa yang diketahui, 23 siswa $(88,5)$ tidak menyampaikan apa yang ditanyakan dan 13 siswa $(42,3 \%)$ tidak menyampaikan dua kesalahan sekaligus yakni apa yng diketahui dan ditanyakan. Pada soal nomor 5 terdapat 10 siswa $(35,6) \%$ tidak menyampaikan apa yang diketahui, 24 siswa $(92,3 \%)$ tidak menyampaikan apa yang ditanyakan dalam soal dan 10 siswa $(36,2 \%)$ tidak menyampaikan dua kesalahan sekaligus.

Merujuk pada pendapat (Sahriah, 2012) mengemukakan bahwa kesalahan mahasiswa terjadi karena (1) mahasiswa tidak mampu menyampaikan hal - hal yang ditanyakan, (2) mahasiswa tidak mampu menyampaikan hal-hal yang diketahui dan ditanyakan, dan (3) mahasiswa mengalami kesalahan dalam menginterpretasi bahasa. Hal ini disebabkan oleh mahasiswa melakukan kesalahan dalam memahami makna soal. 
Mahasiswa yang melakukan kesalahan konsep mengakibatkan mereka tidak mampu menyelesaikan masalah pada tahap berikutnya (Widodo, 2013).Pada tahapan ini siswa yang melakukan kesalahan memahami masalah pada soal nomor 1, 2, 3, 4, dan 5 mampu menyelesaikan pada tahap berikut. sehingga siswa tersebut belum dikategorikan melakukan kesalahan memahami masalah. Hal ini disebabkan pada indikator untuk jenis kesalahan konsep tidak terpenuhi (Widodo, 2013).

Untuk mengetahui mengapa siswa melakukan kesalahan, Wawancara pun dilakukan pada responden 8 .

P : : "Langsung saja ya. Lihat jawaban kamu no.1,2,3,4,5 dan 6, kenapa tidak menuliskan apa yang ditanyakan?"

R8 : "Biasanya kalau mengerjakan soal ya gitu mbak, saya tidak menuliskan apa yang diketahui dan apa yang ditanya Cuma langsung menjawabnya"

P : : 'Ya kenapa begitu dek?'

R8 : "Sudah terbiasa seperti itu mbak, kalau saya mengerjakan soal uraian."

P : : "Itu jangan dibiasakan dek, karena kalau mengerjakan soal matematika uraian harus menuliskan dengan lengkap prosedur pengerjaannya, ya apa yang diketahui, apa yang ditanya dst."

R8 :"Iya mbk, tapi takut kekurangan waktu karena terlalu lama menuliskan apa yang diketahui sama ditanyakan."

P : : "Memangnya kemarin waktunya gak cukup kah?"

R8 : "hehe cukup kok mbk,,"

P : : "Ok. Baik. Lain kali perlu dituliskan secara lengkap prosedur penyelesaiannya, Jangan terbiasa tidak menuliskan apa yang diketahui, apa yang ditanyakan ya.."

R8 : " iya mbak.”

Dari hasil wawancara yang diperoleh, dapat diketahui bahwa siswa yang melakukan kesalahan tidak menuliskan hal - hal yang diketahui dan ditanyakan tetapi bisa menyelesaikan tahap selanjutnya tidak berarti siswa tersebut tidak memahami masalah yang diberikan melainkan siswa sudah terbiasa dalam menyelesaikan soal uraian dengan tidak menuliskan 
apa yang diketahui dan apa yang ditanyakan. Disamping itu alasan lainnya karena takut kehabisan waktu.

\section{Kesalahan Membuat Rencana}

Pada soal nomor 1, diperoleh bahwa 13 siswa (50\%) melakukan kesalahan konsep dan 13 siswa (50\%) melakukan kesalahan prinsip. Soal nomor 2, ada 2 siswa $(7,7 \%)$ melakukan kesalahan konsep dan 2 siswa $(7,7, \%)$ melakukan kesalahan prinsip. Soal nomor 3, terdapat 11 siswa (40,30\%) melakukan kesalahan konsep dan 11 siswa (42,30\%) yang lainnya melakukan kesalahan prinsip. Soal nomor 4, terdapat 4 siswa $(15,8 \%)$ melakukan kesalahan konsep dan 4 siswa $(15,8 \%)$ yang lainnya melakukan kesalahan prinsip. Soal nomor 5, terdapat 5 siswa $(19,2 \%)$ melakukan kesalahan konsep dan 5 siswa $(19,2 \%)$ yang lainnya melakukan kesalahan prinsip.

Kesalahan konsep terjadi dikarenakan siswa tidak memahami konsep pembuktian suatu teorema atau suatu sifat. Siswa yang melakukan kesalahan konsep, jawaban masalahnya hanya sampai pada tahap pertama (memahami masalah). Pada tahap membuat rencana tidak ada langkah - langkah menyelesaikan masalah. Kesalahan prinsip terjadi karena mahasiswa tidak mampu menyampaikan syarat cukup (rumus) dengan benar. (Widodo, 2013).

Untuk mengetahui mengapa siswa tidak mampu membuat rencana, wawancara pun dilakukan pada responden 14 karena telah melakukan kesalahan terbesar pada tahapan membuat rencana. Berikut kutipan wawancaranya :

P : : " Lihat jawaban nomor 1. Mengapa pada tahapan kedua tidak ada jawaban?"

R14 : "saya tidak bisa menyelesaikan masalah ini mbk..."

P : : "Kenapa bisa gitu dek?"

R14 : " ya gak bisa aja mbak..."

Dari hasil wawancara yang diperoleh, dapat diketahui bahwa siswa tidak mampu membuat atau menyusun rencana karena tidak mengetahui rumus apa yang digunakan untuk menyelesaikan masalah tersebut. Siswa hanya menyelesaikan masalah sampai pada tahap pertama (memahami masalah) yaitu menuliskan apa yang diketahui.

\section{Kesalahan Melaksanakan Rencana}

Pada soal nomor 1, diperoleh bahwa 26 siswa $(71,8 \%)$ melakukan kesalahan prinsip dan 24 siswa $(67,9 \%)$ melakukan kesalahan prosedur. Soal nomor 2, terdapat 4 siswa $(13,5 \%)$ 
melakukan kesalahan prinsip dan 7 siswa $(14,1 \%)$ melakukan kesalahan prosedur. Soal nomor 3 , terdapat 8 siswa $(30,77 \%)$ melakukan kesalahan prinsip dan 3 siswa $(67,3 \%)$ melakukan kesalahan prosedur. Soal nomor 4, terdapat 4 siswa $(19,23 \%)$ melakukan kesalahan prinsip dan 4 siswa $(19,9 \%)$ melakukan kesalahan prosedur. Soal nomor 5, terdapat 7 siswa (23\%) melakukan kesalahan prinsip dan 7 siswa $(24,4 \%)$ melakukan kesalahan prosedur.

Kesalahan prinsip terjadi karena siswa tidak mampu menyelesaikan masalah dengan baik (Widodo, 2013). Kesalahan prosedur terjadi karena siswa tidak menuliskan secara benar langkah - langka atau prosedur suatu pengerjaan dan kesalahan algoritma.

Untuk mengetahui alasan siswa melakukan kesalahan tahap tiga (melaksanakan rencana), dilakukan wawancara dengan responden 25.

P : : "Langsung saja, lihat jawaban nomor 2. kenapa disini kamu tidak

menuliskan satu persatu langkahnya, tetapi langsung menjawabnya?"

R25 : "Biar cepet mbak, takut kurang waktunya"

P : :Tapi kemarin nggak nyampai kekurangan waktu kan?

R25 : "Hehe nggak mbak"

P : :Dalam mengerjakan soal uraian diusahakan menuliskan perlangkahnya, agar dapat diketahui hasil - hasil yang diperoleh itu dari mana dan lebih jelas cara kerjanya".

R25 : "Iya mbak"

Dari hasil wawancara yang diperoleh, siswa tidak menuliskan langkah - langkah secara runtut karena takut kehabisan waktu.

\section{Kesalahan Memeriksa Kembali Jawaban}

Pada tahapan ini, siswa yang melakukan kesalahan meeriksa kembali jawaban soal nomor 1 , terdapat 14 siswa $(53,85 \%)$. Soal nomor 2 , terdapat 3 siswa $(11,54 \%)$. Soal nomor 3, terdapat 20 siswa $(76,90 \%)$. Soal nomor 4 , terdapat 11 siswa $(42,30 \%)$. Sola nomor 5, terdapat 6 siswa $(23 \%)$.

Pada tahapan ini mayoritas siswa tidak melakukan pemeriksaan kembali hasil pekerjaannya sebelum dikumpul, akibatnya beberapa siswa yang melakukan kesalahan pada hasil akhir, kesalahan prosedur dan kesalahan konsep.

\section{KESIMPULAN}


Jurnal PRISMA Universitas Suryakancana

Hasil penelitian menunjukkan bahwa prensentase kesalahan siswa dalammenyelesaikan masalah matematika menggunakan langkah Polya adalah pada tahapan pertama persentase kesalahan siswa sebesar 49,36\%, tahapan kedua 26,92\%, tahapan ketiga $34,16 \%$ dan tahapan keempat 41,5\%.

Dari keempat kesalahan yaitu kesalahan memahami masalah (Understanding the plan), kesalahan membuat atau menyusun rencana (Devising a plan), kesalahan melaksanakan rencana (Carrying out the plan) dan kesalahan memeriksa kembali jawaban (Looking back) dapat diketahui bahwa jenis kesalahan terbanyak yang dilakukan siswa kelas VII SMP Taman Siswa Tahun Ajaran 2016/2017 dalam menyelesaikan masalah matematika pada materi himpunan adalah kesalahan Memahami masalah yaitu sebesar 49,36\% dan termasuk dalam kategori Cukup.

\section{REFERENSI}

Hudojo, H. (2005). Pengembangan Kurikulum dan Pembelajaran Matematika. Malang : UM Press

Komariah, A., \& Satori, D. (2014). Metode penelitian kualitatif. Bandung : CV Alfabeta Meleong, L. J. (2000). Metode Penelitian Kualitatif. Bandung: PT Remaja Rosdakarya Sahriah. (2012). Analisis Kesalahan Siswa dalam Menyelesaikan Soal Matematika Materi Operasi Pecahan Bentuk Aljabar Kelas VIII SMP Negeri 2 Malang. Jurnal Pendidikan Matematika. 1(1).

Suyitno, A. (2004). Dasar - dasar dan Proses Pembelajaran Matematika I. Semarang: Pendidikan Matematika FMIPAUNNES

Syah, M. (2005). Psikologi Pendidikan dengan Pendekatan Baru. Bandung: PT Remaja Rosdakarya

Suherman, dkk. (2001). Strategi Pembelajaran Matematika Kontemporer. Bandung: UPI Sugiyono. (2010). Metode Penelitian Pendidikan. Bandung: CV Alfabeta

Uno, H. B. (2008). Teori Motivasi dan Pengukurannya. Jakarta : Bumi Aksara

Widodo, S. A. 2013. Analisis Kesalahan Dalam Pemecahan Masalah Divergensi Tipe Membuktikan Pada Mahasiswa Matematika. Jurnal Pendidikan dan Pengajaran. 46(2), Hal $106-113$ 